\title{
Reducing Produced Water with Density and Conductivity Meters
}

\section{Final Report}

February 17, 2003

May 16, 2004

Jason T. Smith

August 2004

DE-FG26-03NT15434

Team Energy

RR1 Box 197

Bridgeport, IL 62417 


\section{DISCLAIMER}

"This report was prepared as an account of work sponsored by an agency of the United States Government. Neither the United States Government nor any agency thereof, nor any of their employees, makes any warranty, express or implied, or assumes any legal liability or responsibility for the accuracy, completeness, or usefulness of any information, apparatus, product, or process disclosed, or represents that its use would not infringe privately owned rights. Reference herein to any specific commercial product, process, or service by trade name, trademark, manufacturer, or otherwise does not necessarily constitute or imply its endorsement, recommendation, or favoring by the United States Government or any agency thereof. The views and opinions of authors expressed herein do not necessarily state or reflect those of the United States Government or any agency thereof." 


\begin{abstract}
The work performed was an attempt to reduce the amount of produced water by using the well bore as an oil-water separator. The use of a flow meter, density meter and/or conductivity meter controlling a pumping unit would be used to achieve this goal. The natural physical differences between oil and water are easily detected inside the production stream with proper equipment. A coriolis mass meter, conductivity meter, data recorder, timer and relays were purchased and housed in a purpose-built field cabinet.

The metering unit was hooked to four wells over the course of the project, Spencer \#8, Applegate Gray Unit \#1 (AGU \#1), Vollmer \#4 and Mohr \#1. All are located in the Illinois Basin, three with artificial lift pumps and one flowing well. Depth of producing formations ranges from a maximum of $846.13 \mathrm{~m}(2776 \mathrm{ft})$ to minimum of $316.69 \mathrm{~m}$ (1039 ft). All wells were completed in one formation of Mississippian or Pennsylvanian age.

The data recorded were analyzed to determine what events could be detected. Events included pure oil or higher oil-cut fluid reaching the pump or reaching the metering equipment, the pump operating under capacity, and the well "pumped down". Based on how much oil and water is present in a fluid column, the pressure the fluid column imparts on a formation can be calculated. By knowing the amount of oil and water in a well bore and the maximum height water can reach, production equipment can be configured to only produce oil. However, the configuration may not be profitable. It became apparent during the course of this research the wells tested do not have an oilwater contact deep enough so traditional pumping equipment can be configured to recover oil by the proposed method. This method may work more successfully in deeper basins. Other interesting anomalies were also detected in the data.
\end{abstract}




\section{Table of Contents}

Disclaimer

Abstract

Executive Summary

Introduction

Experimental

Figure 1

Figure 2

Figure 3

Figure 4

Figure 5

Figure 6

Figure 7

Figure 8

Figure 9

Figure 10

Figure 11

Figure 12
Page 2

Page 3

Page 5

Page 6

Page 6

Page 11

Page 12

Page 13

Page 14

Page 15

Page 16

Page 17

Page 18

Page 19

Page 20

Page 21

Page 22 


\section{Executive Summary}

The work performed was an attempt to reduce the amount of produced water by using the well bore as an oil-water separator. The use of a flow meter, density meter and/or conductivity meter controlling a pumping unit would be used to achieve this goal. The natural physical differences between oil and water are easily detected inside the production stream with proper equipment. A coriolis mass meter, conductivity meter, data recorder, timer and relays were purchased and housed in a purpose-built field cabinet.

The metering unit was hooked to four wells over the course of the project, Spencer \#8, Applegate Gray Unit \#1 (AGU \#1), Vollmer \#4 and Mohr \#1. All are located in the Illinois Basin, three with artificial lift pumps and one flowing well. Depth of producing formations ranged from a maximum of $846.13 \mathrm{~m}(2776 \mathrm{ft})$ to minimum of $316.69 \mathrm{~m}$ (1039 ft). All wells were completed in one formation of Mississippian or Pennsylvanian age.

The data recorded were analyzed to determine what events could be detected. Events included pure oil or higher oil-cut fluid reaching the pump or reaching the metering equipment, the pump operating under capacity, and the well "pumped down". Based on the graphical data, it was determined that the flow data shows oil to pump by an increase in flow rate or an arrest in decline of flow rate due to oil's higher viscosity. Flow data also shows pump down by a sudden drop in flow rate or arrest in decline of flow rate.

Based on how much oil and water are present in a fluid column, the pressure the fluid column imparts on a formation can be calculated. By knowing the amount of oil and water in a well bore and the maximum height water can reach, production equipment can be configured to only produce oil. However, the configuration may not be profitable. It became apparent during the course of this research the wells tested do not have an oilwater contact deep enough so traditional pumping equipment can be configured to recover oil by the proposed method. This method may work in deeper basins where the oil-water contact can be much deeper.

Other interesting anomalies were also detected in the data. The density of the produced fluid fluctuates over time, and rod stretch in the production string can be detected.

Conversion factors were obtained from Schlumberger's iHandbook ${ }^{\circledR}$; a copy can be found at http://www.slb.com/oilfield/ihandbook/. 


\section{Introduction}

The purpose of this project was to determine if wells could be configured so water production could be minimized by using the well bore as an oil-water separator. In order to be able to use the well bore as an oil-water separator, the depth to the oil-water contact would have to be determined. The oil-water contact was determined using a flow meter and a density meter recording data every second. Four wells were tested in the Illinois Basin, three with artificial lift pumps and one flowing well. Depth of producing formations ranged from a maximum of $846.13 \mathrm{~m}(2776 \mathrm{ft})$ to minimum of $316.69 \mathrm{~m}$ $(1039 \mathrm{ft})$. All wells were completed in one formation of Mississippian or Pennsylvanian age. Two were considered uneconomic, Spencer \#8 and Applegate Gray Unit \#1 (AGU \#1), and two were economic, Vollmer \#4 and Mohr \#1. The wells could then be configured to increase their economic life and ultimately increase reserves.

Conversion factors used during the project were obtained from Schlumberger's iHandbook $^{\circledR}$; a copy can be obtained at http://www.slb.com/oilfield/ihandbook/ at the bottom of the web page.

\section{Experimental}

The cabinet was assembled and initially tested at the Team Energy L.L.C. tool yard. The instrument is named the Oil Cut Enhancement System or OCES (pronounced "oaks"). Fluid flow was tested using a garden pond pump flowing vegetable oil and calcium chloride water. It became apparent the conductivity meter was going to have some difficulty quickly reading fluid property changes due to the cell required to hold the probe. The cell was $10.16 \mathrm{~cm}$ (4") in diameter and the $2.54 \mathrm{~cm}$ (1") piping entering it caused a delay in the fluid sweeping the housing "clean" of the previous fluid. It was hoped the larger volume from a producing well would decrease the amount of time required to clean the cell, allowing it to be useful.

In the field, fluid from a well was directed to the OCES cabinet housing the metering devices from the wellhead via $2.54 \mathrm{~cm}$ (1"), high-pressure hoses. After leaving the unit, the fluid was transported via flow lines to the stock tanks. Inside the cabinet, the fluid first went through the mass meter where fluid density and flow rates where measured and recorded. A pressure transducer and mechanical pressure gauge were installed on the downstream side of the mass meter. An adjustable, backpressure valve was installed past the pressure gauges. The pressure on the mass meter was maintained by the valve in an attempt to keep gases from evolving out of the oil. From the backpressure valve the fluid passed through the conductivity meter where its value was recorded, then into the flow line and to the stock tanks. All data were recorded every second.

OCES was deployed onto the Mohr 1 well in Posey County, Indiana, on July 9, 2003. However, OCES was lacking a control device to turn the pumping unit off and on. Once the unit was connected in line to a pumping well several problems became apparent. The discontinuous flow rate produced by normal down-hole pumps was causing the density meter reading to fluctuate too much, causing "noisy" readings. The density reading was further degraded from the gas coming out of the oil when hydrostatic head was released during fluid production. The conductivity meter would not read continuously. Once the cell housing in the conductivity meter was full of fluid it worked correctly. A wrong assumption was made that a producing well would be able to keep 
the cell full of fluid. However, gas evolving out of the oil and the downward flow of fluid through the meter causes a gas pocket to form in the cell, leaving the probe "dry".

The negative affect of entrained gas was anticipated and a backpressure valve was installed before deployment. However, a constant backpressure is critical for steady density readings. The pressure fluctuates due to the nature of the down-hole pump. The noisy density reading was further minimized by installing a surge pot in the flow line between the wellhead and OCES. As an additional step to "smooth out" the density reading, the sampling rate was changed on the density meter, from one second per sample to two and a half seconds per sample.

The flow through the conductivity meter was rerouted so that an upward flow was obtained and an air valve was installed to remove the gas from the cell. The two corrections allowed the conductivity meter to provide good data but it still did not respond as fast as was hoped; therefore it was used to confirm readings from the density meter.

On August 27, 2003 a PLC (process logic control) device was installed along with OCES. A PLC consists of a timer and a series of relays to stop and start the well. An AC current transducer was also installed to monitor the power consumed by the pumping unit and provide additional data on the running status of the well.

Data were displayed graphically and interpretations of significant repeatable events can be detected (Figure 1). The events are: oil reaching the down hole pump, oil reaching the surface, pump not pumping at full capacity, and rate of fluid deliverability to the well bore. An example is shown in Figure 2. Each well's graphical data will have a different appearance due to the fluid properties and production equipment configurations. An additional example is shown in Figure 3.

By looking at the graphical data it was determined that the flow data shows oil to pump by an increase in flow rate or an arrest in decline of flow rate due to oil's higher viscosity. Flow data also shows pump down by a sudden drop in flow rate or arrest in decline of flow rate (Figures 1, $2 \& 3$ ). The AC ampere transducer confirms pump down by a drop of consumption or an arrest in increase of consumption of amperes and therefore power used to move fluid (Figure 3).

When exacting numbers were required for calculations the data was downloaded into an Excel $^{\circledR}$ spreadsheet. For example, flow rates were converted into volumes by summing the data points and dividing by 3600 , since rates were recorded in $\mathrm{m}^{3} / \mathrm{hr}$.

In the course of obtaining the data it became apparent that if the well bore could serve as an oil-water separator so that conventional equipment at the well site produces only oil, the static fluid level needs to be at some depth below the surface. For wells that have fluid to surface, the casing can act as an artificial static fluid level. However, significant modification would be required to allow pumping units designed to produce fluids from hundreds of feet below surface to withdraw fluid from tens of feet. Much smaller production equipment or a different method of production is required in order for water-free production to be obtained with the pump set $30 \mathrm{~m}$ to $60 \mathrm{~m}$ (100 ft to $200 \mathrm{ft}$ ) from surface. The time and cost to modify pumping equipment exceeds the budgeted amounts for the current test and is another problem to solve. The shut down time required to build a pad of oil on top of the water column will cause the oil-water contact to move above the pump setting, requiring water removal before oil can be produced. Producing the water defeats the tested pumping method. In theory, the static fluid level 
can be used to keep the oil-water contact from migrating up the well bore from a maximum level, but can be lowered over time if the withdrawal of oil is less than the inflow of oil.

A unique situation occurred during testing of the Applegate-Gray Unit \#1 well (AGU \#1). It had been inactive for more than a year and during reactivation the production string had to been removed to test tubing and replace the down-hole pump. When the production string was replaced it allowed the amount of oil and water in the static fluid column to be measured. Knowing the amount of oil, water, and their densities the pressure on the formation for static conditions could be calculated. Using the calculated formation pressure, the height of a pure water column the formation can hold was calculated. It was assumed if the pump was set at the calculated depth the well would not be allowed to produce water, only oil. Before production started the fluid level was detected with an acoustic meter. The well was allowed to pump the oil off the top of the fluid column inside the production string and its volume was calculated from the data recorded and translated into the height of oil column, which was calculated to be $134.5 \mathrm{~m}$ (441.2 ft). The oil height was subtracted from the known height provided by the acoustic meter. The densities of the fluids were obtained by direct measurements read from the recorded data. The pump was raised in the well $152 \mathrm{~m}$ (500ft) and was allowed to pump. The fluid recovered was all oil. However, the rate of withdrawal was uneconomic at $0.009 \mathrm{~m}^{3} /$ day $(0.056 \mathrm{bbl} /$ day $)$.

Information obtained from the data on the Mohr 1 was used to calculate pressure on the formation. Since the density of the fluid and the volume of water and oil can be reasonably measured, the height of the total fluid column can be calculated by recording the volume of total fluid withdrawn before pump down. The amount of oil on top of the fluid column can be determined from the volume pumped after oil reaches the pump. The inflow of new fluid into the well bore must be considered to obtain accurate volumes. The inflow of fluid increases as the fluid height, and therefore the pressure, on the formation is lowered. The unknown rate of inflow increase causes error in the pressure calculations, resulting in calculated pressures that are too low. By calculating formation pressures for different withdrawal rates, a performance curve was generated. A timer was used to run the well for six minutes per hour and nine minutes per hour, resulting in withdrawal rates of $0.021 \mathrm{~m}^{3} / \mathrm{hr}(0.132 \mathrm{bbl} / \mathrm{hr})$ and $0.030 \mathrm{~m}^{3} / \mathrm{hr}(0.189 \mathrm{bbl} / \mathrm{hr})$ per hour respectively. The well was allowed to run in the above configuration until fluid level was at equilibrium. The well was then pumped down and the volumes calculated. The change in inflow rates during pump down was $0.021 \mathrm{~m}^{3} / \mathrm{hr}(0.132 \mathrm{bbl} / \mathrm{hr})$ to 0.089 $\mathrm{m}^{3} / \mathrm{hr}(0.560 \mathrm{bbl} / \mathrm{hr})$ and $0.030 \mathrm{~m}^{3} / \mathrm{hr}(0.189 \mathrm{bbl} / \mathrm{hr})$ to $0.087 \mathrm{~m}^{3} / \mathrm{hr}(0.547 \mathrm{bbl} / \mathrm{hr})$. Other data points were acquired by raising the pump in the well, creating pressure on the formation from the higher fluid column. The result of the performance curve, inflow vs. pressure, is shown in figure 4.

A timer was installed on the Spencer \#8 well and on-off times were accurately adjusted using data collected in the manner described above. The times on and off were determined based on inflow and withdrawal rates. Inflow into the well was found to be $0.097 \mathrm{~m}^{3} / \mathrm{hr}(0.610 \mathrm{bbl} / \mathrm{hr})$. Fluid withdrawal moments before pump down were found to be $0.305 \mathrm{~m}^{3} / \mathrm{hr}(1.918 \mathrm{bbl} / \mathrm{hr})$. Subtracting inflow from withdrawal, a net withdrawal of $0.208 \mathrm{~m}^{3} / \mathrm{hr}(1.308 \mathrm{bbl} / \mathrm{hr})$ was calculated. Therefore, the optimal pumping cycle was 15 
minutes off and 7 minutes on, under current reservoir conditions. A timer was installed to make the well produce at the optimal setting.

The Spencer \#8 well was the only well producing to the tank battery, allowing for a comparison between gauged production and metered production. On the Spencer \#8 well, as with all others, the percentage of oil was calculated by first finding the density of pure oil and pure water. Pure oil is produced after the well has been inactive for a short time i.e. 12 hours +/-. During the idle time, the oil and water inside the tubing separates. When the well begins pumping, it will first produce slugs of pure oil, then pure water (Figure 6). The densities of oil and water can be read directly from the recorder. The two densities become the end points for a simple $\mathrm{y}=\mathrm{mx}+\mathrm{b}$ equation used to compute percent oil. After programming, the recorder was capable of calculating the percent of oil and multiplying it by the rate of fluid, yielding a rate of oil. Over the 28 days data were recorded the gauge production was $10.70 \mathrm{~m}^{3}(67.28 \mathrm{bbl})$ and metered production was $11.67 \mathrm{~m}^{3}(73.41)$. The actual daily production can be found in figure 7 . The metered volume was expected to be greater, since entrained gas would cause the density meter to read low, causing the algorithm to calculate a higher oil volume. At the stock tanks, the gas dissipates, reducing the amount of oil to be gauged. Other information that might be useful included the rate of fluid level drop in the annular space, which was calculated to be a rate of $37.06 \mathrm{~m} / \mathrm{hr}(121.6 \mathrm{ft} / \mathrm{hr})$ based on $5 \frac{1}{2}$ " casing and $2 \frac{3}{8}$ " tubing.

The last well to be tested was the Vollmer \#4. This well produces fluid without the aid of artificial lift, and is allowed to flow one day per week. The data shows very little time is spent flowing pure oil. However, an appreciable amount of oil is produced by continued flow (Figure 8$)$. Pure oil flow produces only $0.078 \mathrm{~m}^{3}(0.491 \mathrm{bbl})$ while a continued flow generates an additional $.933 \mathrm{~m}^{3}(5.87 \mathrm{bbl})$. Field personnel report they allow the Vollmer \#4 to flow on the day they chemically treat the other active producing well on the lease, which makes the Vollmer \#4 the only active well producing into the tank battery. Under these circumstances, the Vollmer \#4 gauge production can be checked vs. metered production. The gauge production for the test day was $1.07 \mathrm{~m}^{3}(6.75$ bbl), and metered production was $1.01 \mathrm{~m}^{3}$ (6.36 bbl).

While analyzing the data some interesting anomalies were revealed. The density of the produced fluid fluctuates over time in the Spencer 8 well (Figure 9). Why the well produces fluid with density fluctuations is unknown, but is believed to be actual fluid property changes because of both the density and conductivity meter response. The density response was a decrease in density i.e. greater percentage of oil in the fluid. The conductivity decrease was an indication of more resistive fluid; in other words, a higher concentration of oil is passing through the metering equipment. Is the changing fluid property caused by a differential flow, due to viscosity differences between oil and water?

Peaks and valleys observed in the flow data are due primarily to mechanical stretch of the rods. Examples were found in three wells at varying intensities (Figures 10, 11 and 12). One cycle of flow represents one stroke of the pumping unit, as best seen in figures 10 and 12. The power consumption was also effected in the Mohr \#1 well, correlating with the fluid changes. If the fluid pumped decreased due to rods stretching and contracting like a spring, the effective stroke at the pump would be reduced for a short time, causing a reduction in work performed by the rod string and flow. The effect 
is not as noticeable in shallower wells or when the well is pumped down (Figures 11 and 12).

\section{Discussion}

In order for the well bore to be used as an oil-water separator the reservoir conditions must be such to allow oil to flow at economic rates. The rate of oil withdrawal must be equal to inflow of oil and not just total fluid. After a well has been shut down, inflow of oil will be some percentage of a previous rate. If the percentage is one percent and the lowest economic rate is $0.159 \mathrm{~m}^{3} \mathrm{OPD}$ (1 BOPD) that means the well would have to produce at a rate of $15.88 \mathrm{~m}^{3} \mathrm{OPD}$ (100 BOPD) sometime in the past, in order for the tested method to work. Further fieldwork is required to tell if initial production could be used as a parameter for choosing test well candidates. Deeper wells would have a higher probability of being effective oil-water separators because they have more depth in which to work and generally have higher rates of production. Also, the deeper the well, the higher the column of fluid may be, and hence, more pressure on the formation can occur.

\section{Conclusion}

The wells tested did not have the reservoir characteristics required to make the tested method work economically. The closest candidate would be the Mohr \#1.

However, it would require raising the pump very close to the surface and rebalancing the pumping unit, possibly replacing the rod string or utilize a unique method of production. Useful information can be obtained with a good flow meter and a method to record its data. Knowing oil and water densities one can calculate the pressure on the formation within an acceptable margin of error. If a timer is to be used on low volume wells, on-off times can be quickly and accurately determined. In unique situations the density meter can be used to calculate formation pressure with higher precision due to better measurement of oil height. 


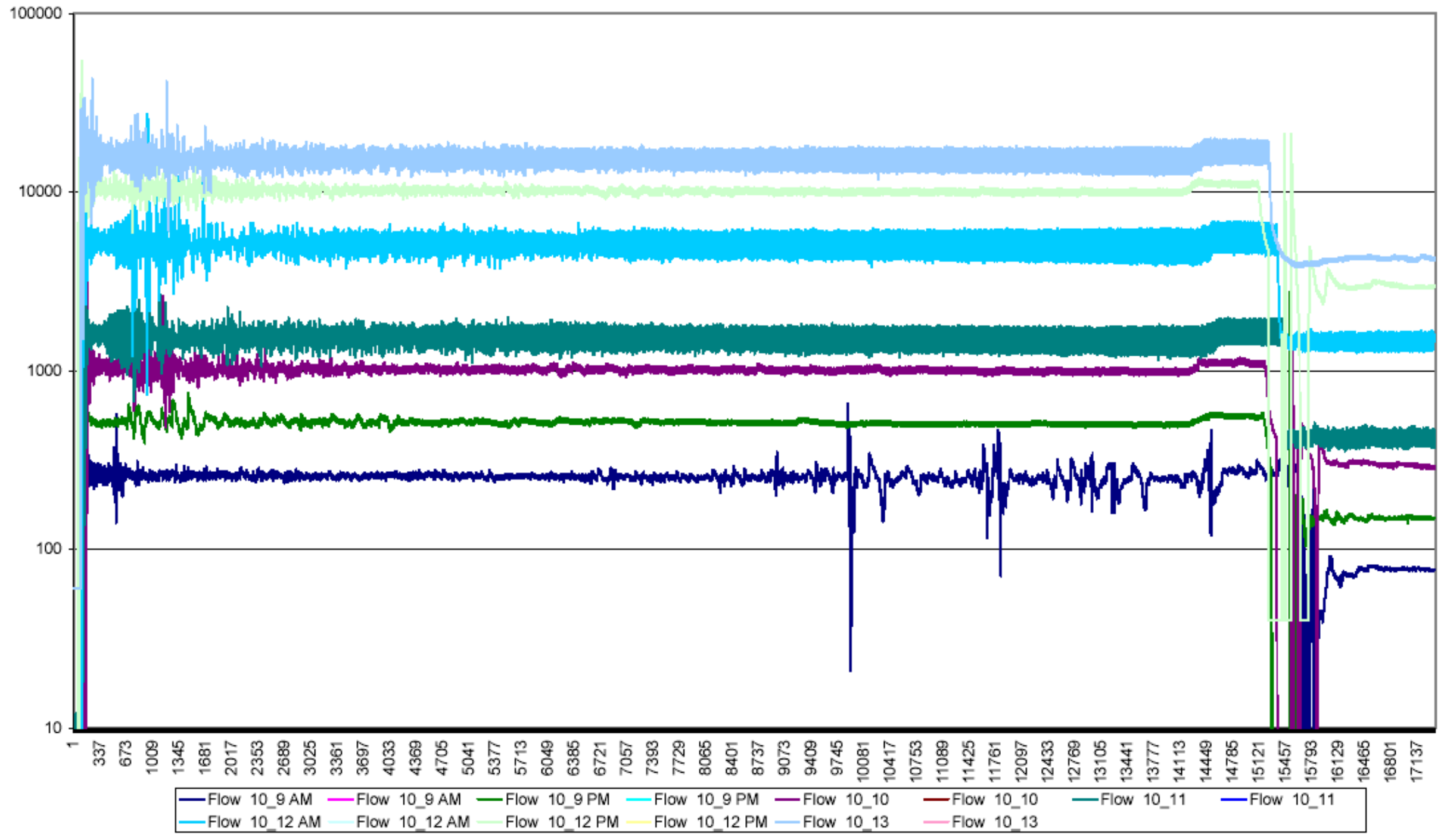

Figure 1

Flow data taken from seven pump down cycles on the Mohr \#1. The x value represents data point for each cycle. The y value represents actual data multiplied by a factor so that it could be spread out over a logarithmic scale. The interpretations are further explained in figure 2 

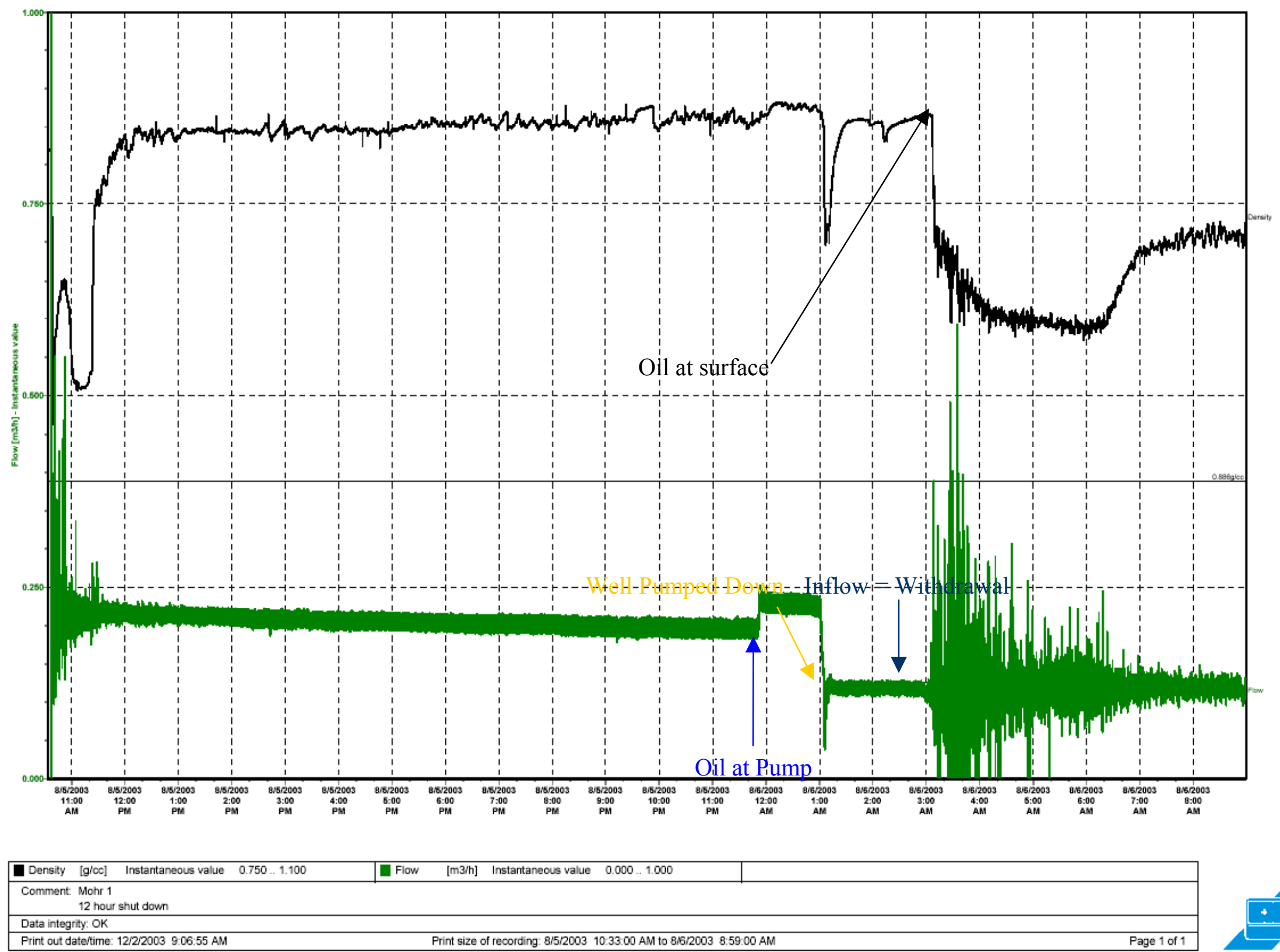

Figure 2

Graphical data from Mohr 1 well used to interpret events during pump down. Green line is flow rate; black line is fluid density. 


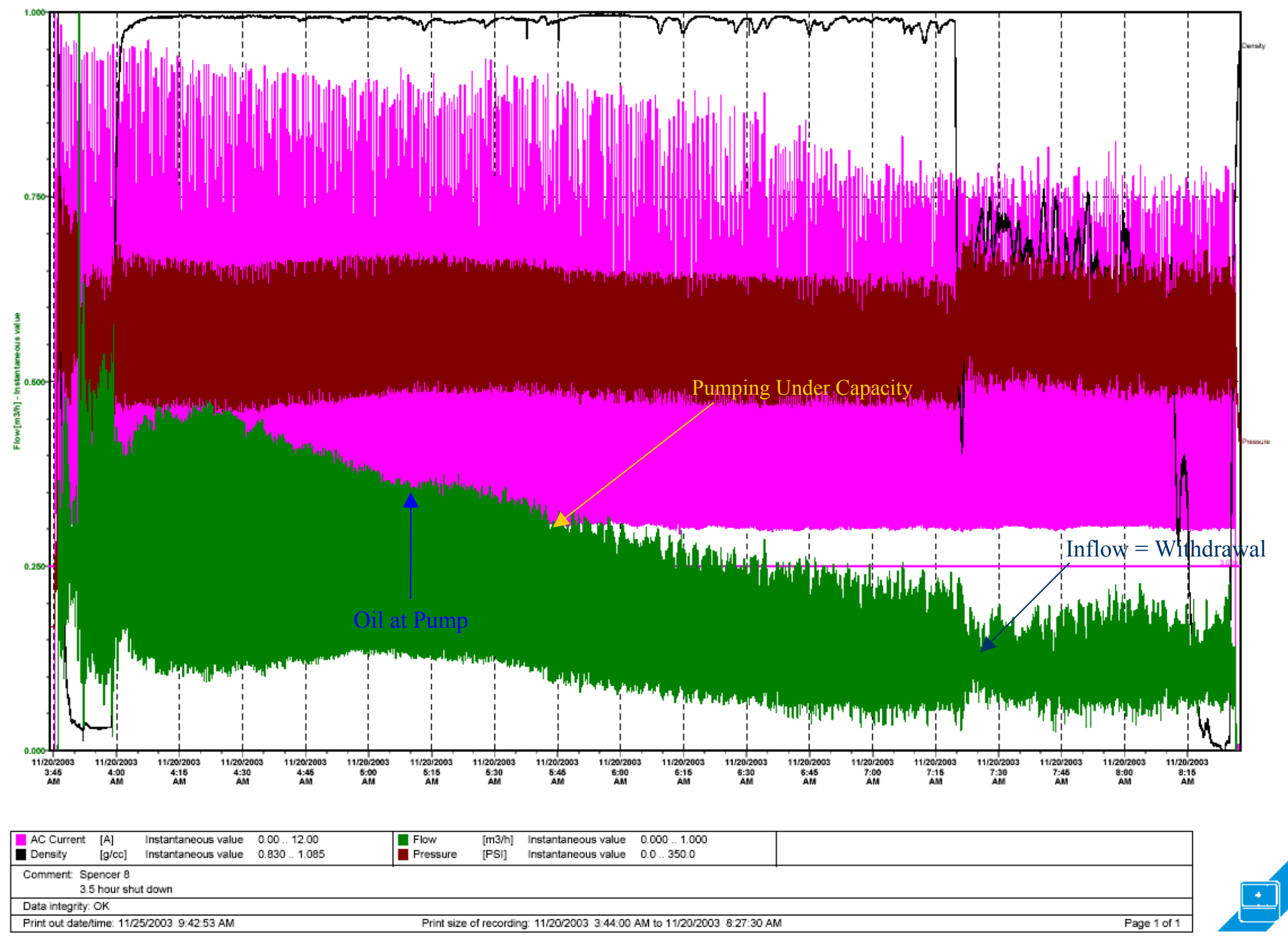

Figure 3

Spencer 2 well data; Green line is flow rate, black line is fluid density, pink line is AC current, and brown line is pressure. 


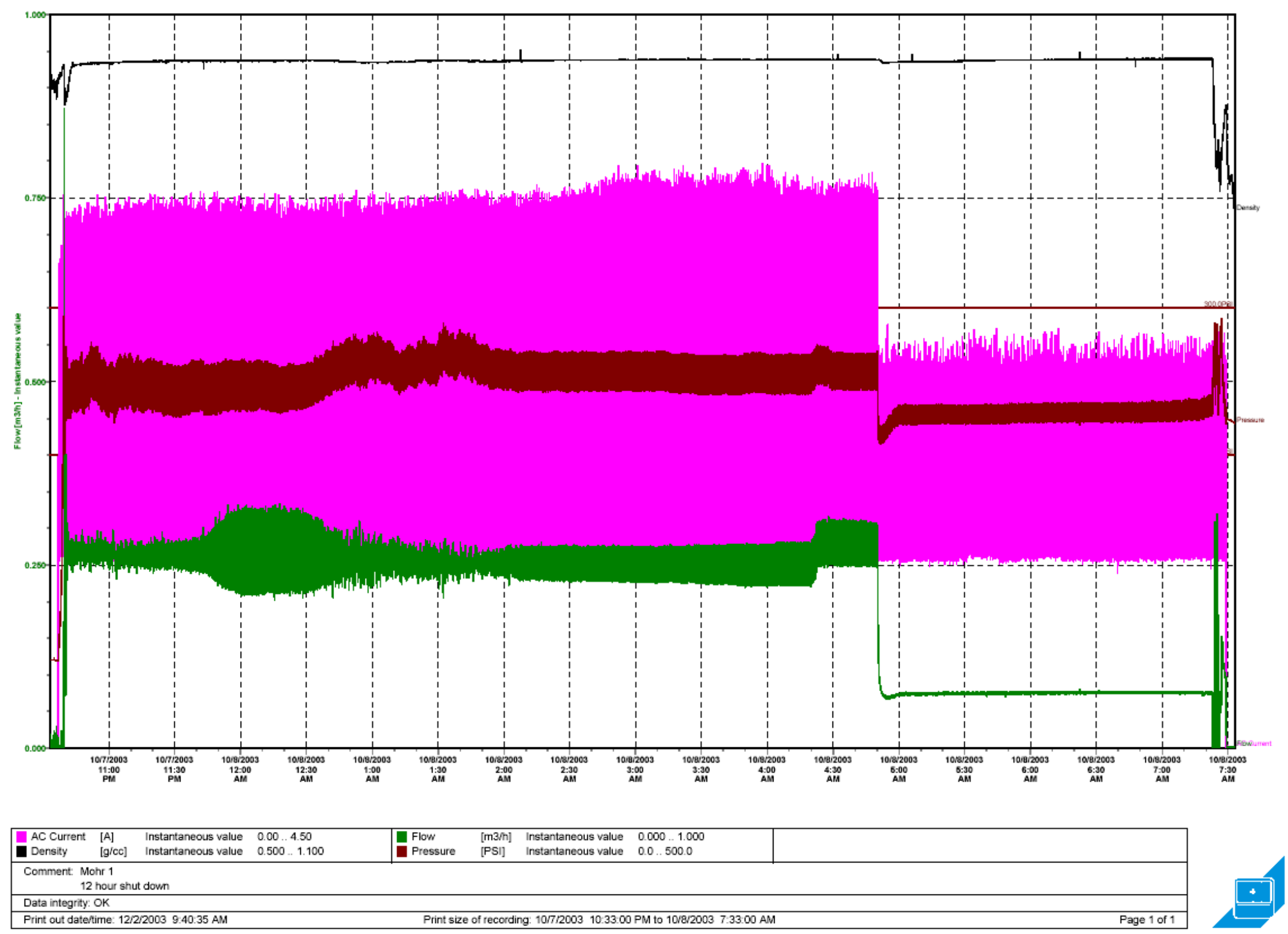

Figure 4

Pump down of the Mohr 1 after 12 hour shut down and the pump set at $619.96 \mathrm{~m}$ (2034ft). Green line is flow rate, black line is fluid density, pink line is AC current, and brown line is pressure. When the $\mathrm{AC}$ current is greater than zero the pump is active. 


\section{Inflow vs. Formation Pressure}

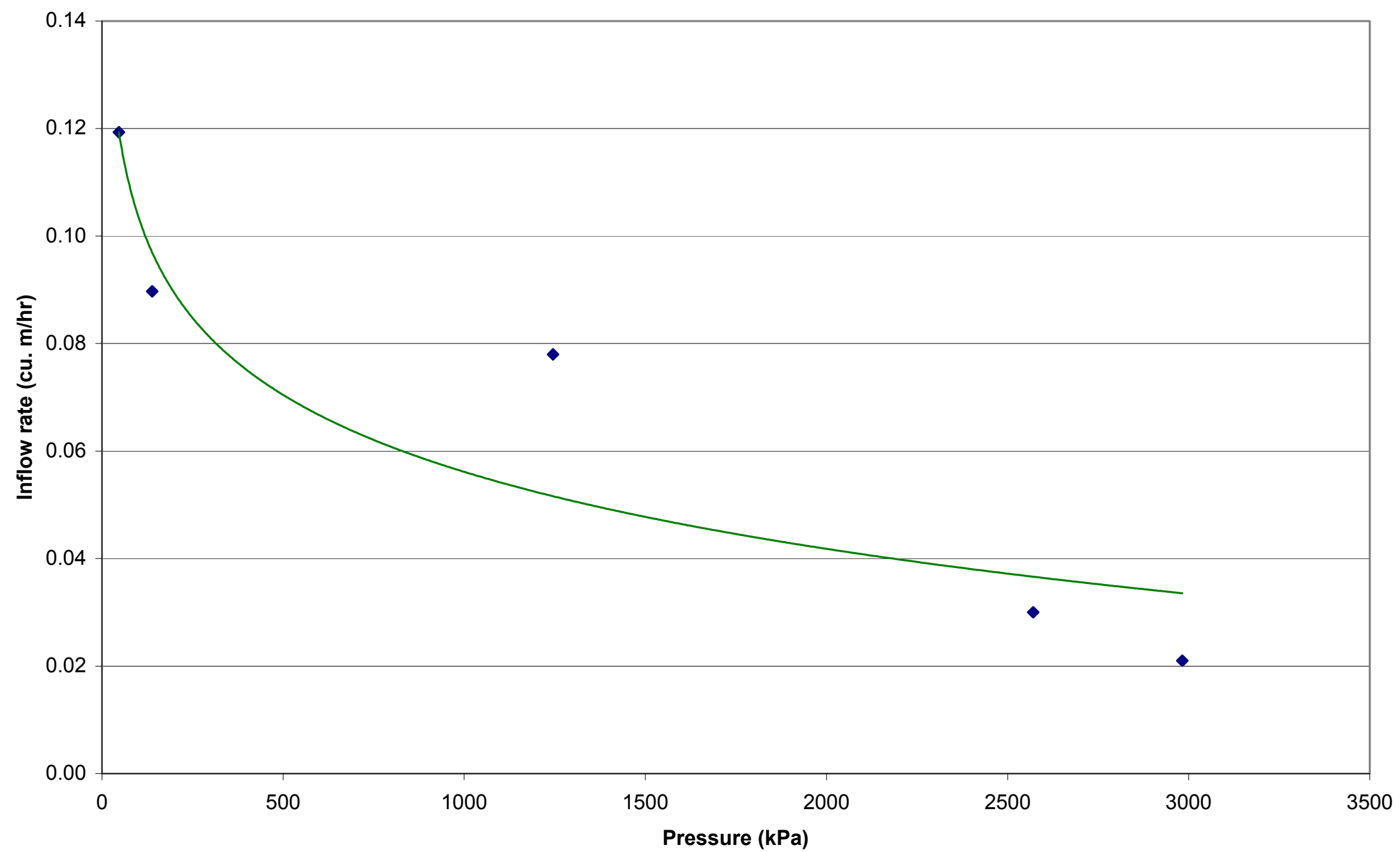

Figure 5:

Inflow vs Pressure for the Mohr 1 well. The points to the left of and including $1250 \mathrm{kPa}$ were obtained from changing pump height. The points to the right were obtained from calculations based on OCES data generated during pump down after withdrawing a known volume of fluid per hour. The well was allowed to reach an equilibrium, generating an artificially low "static" fluid level. The green curve was generated using Excel $^{\circledR}$ exponential trend line function. 


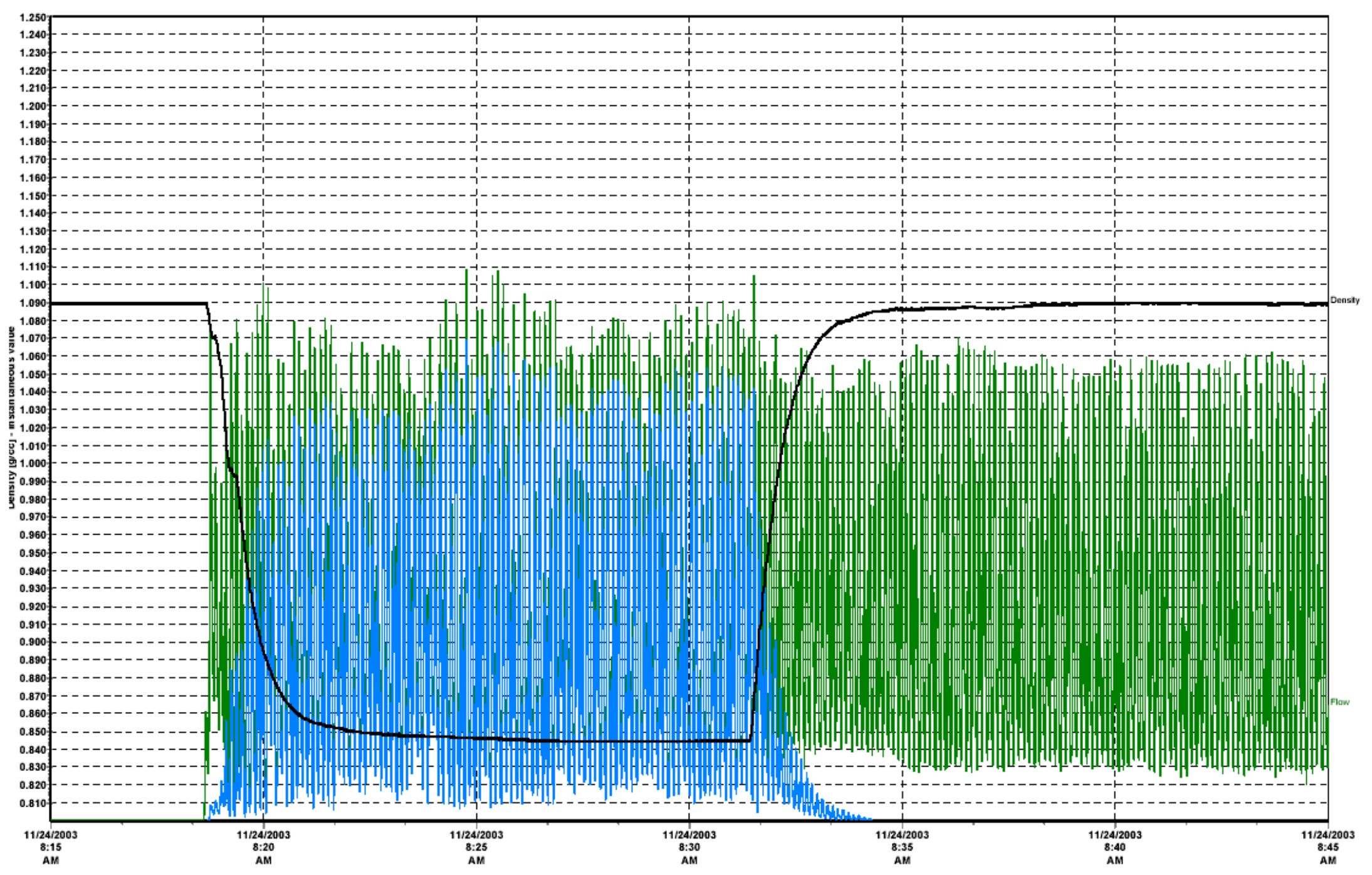

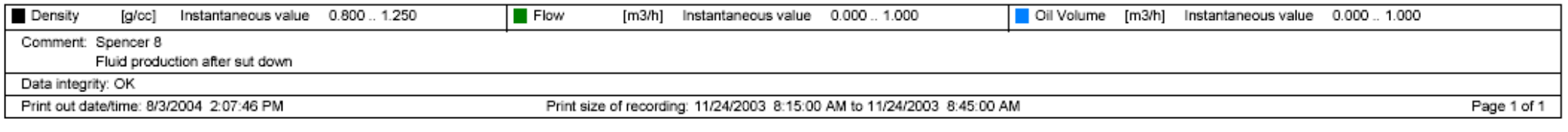

Figure 6

Fluid properties from the Spencer \#8 well after it had been idle for 3.5 hours. Green line is fluid flow, Black line is fluid density, and the Blue line is calculated oil volume produced. 


\section{Production Gauged Vs. Metered}

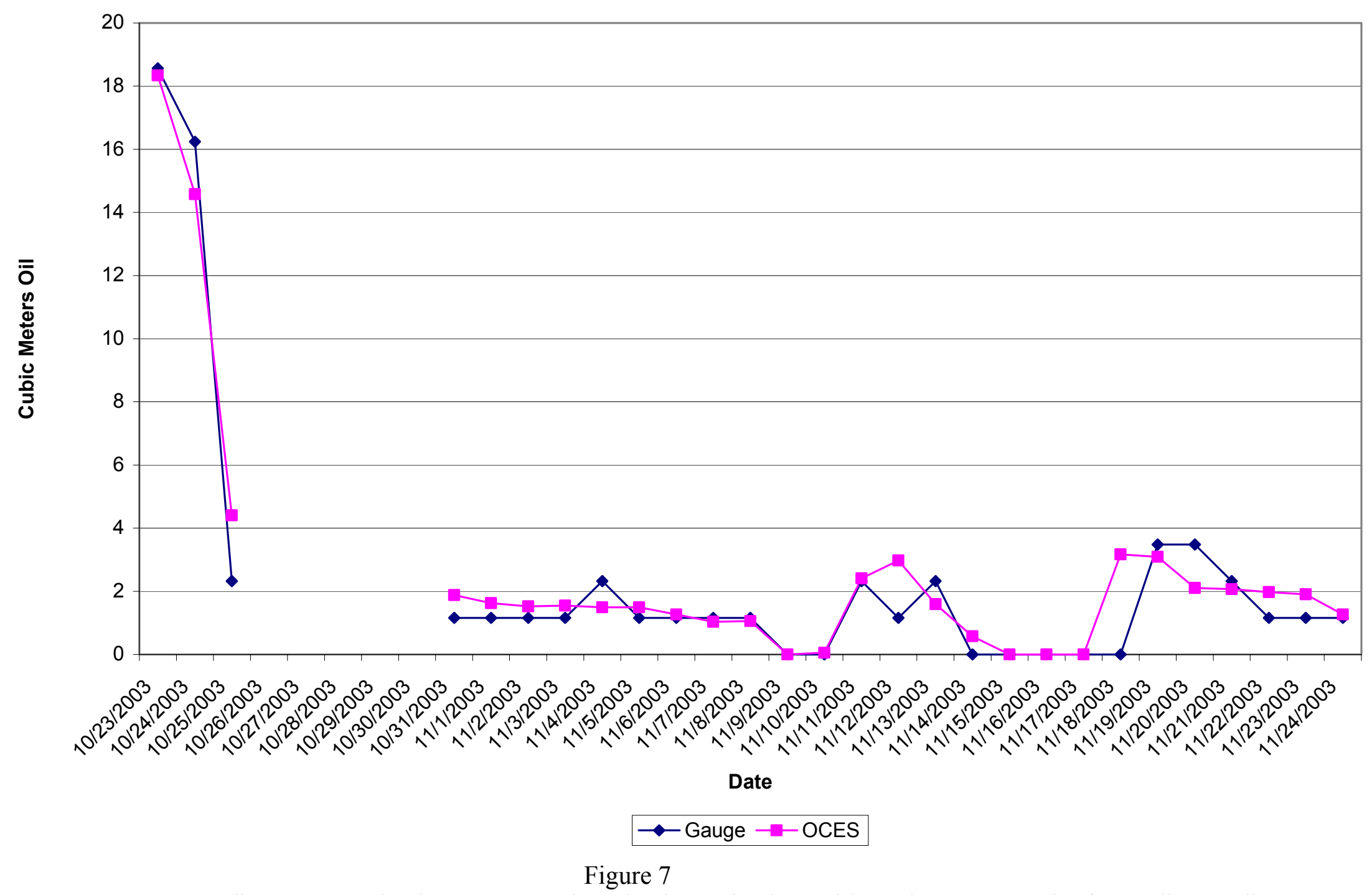

Spencer \#8 Gauge production vs. metered production. The days without data are a result of recording media failure and/or gas interference with the density meter. 


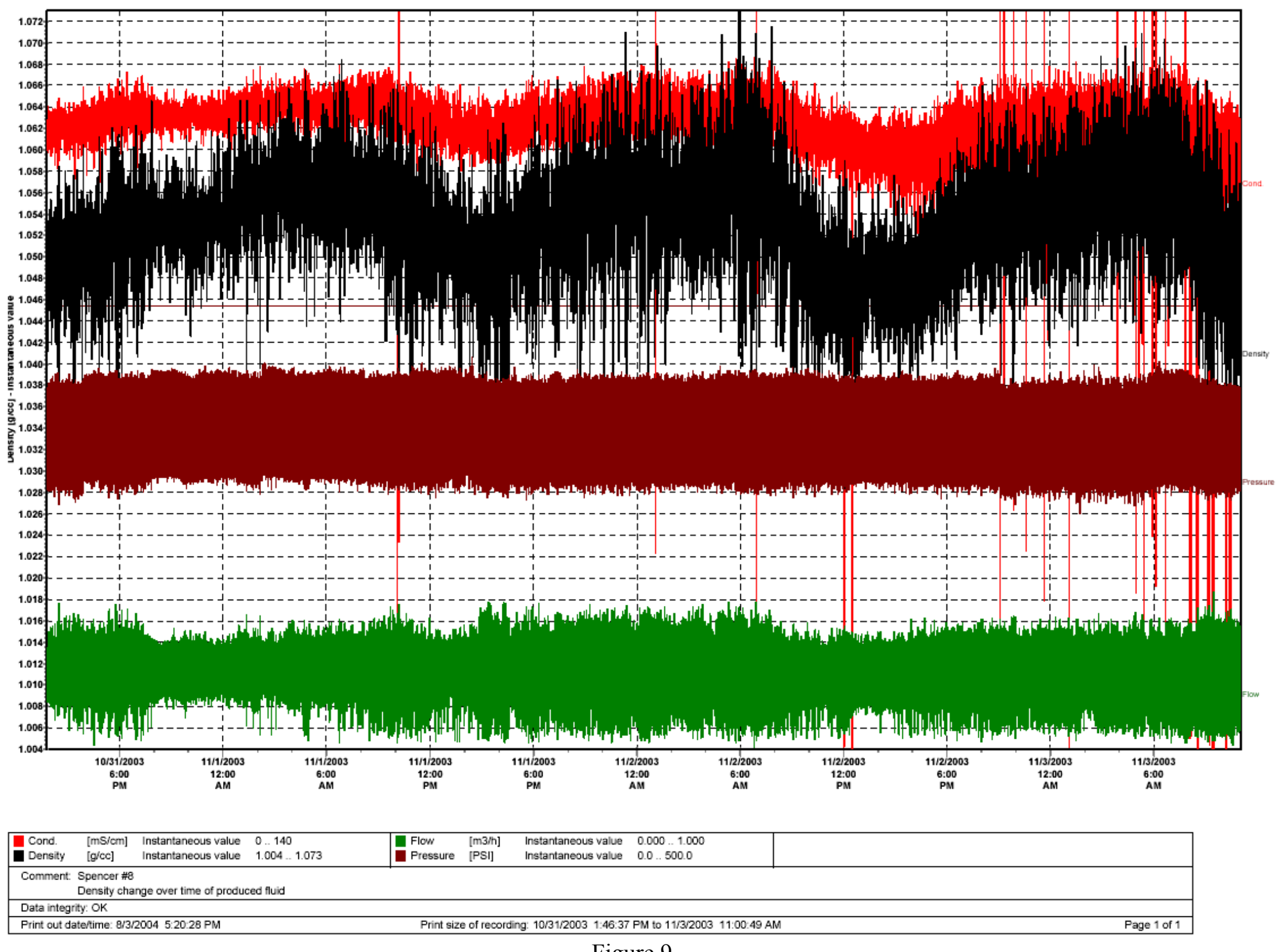

Figure 9

Changing density of produced fluid over time from the Spencer \#8 well. Black line is density. Red line is conductivity. Green line is flow rate. Brown line is pressure. 

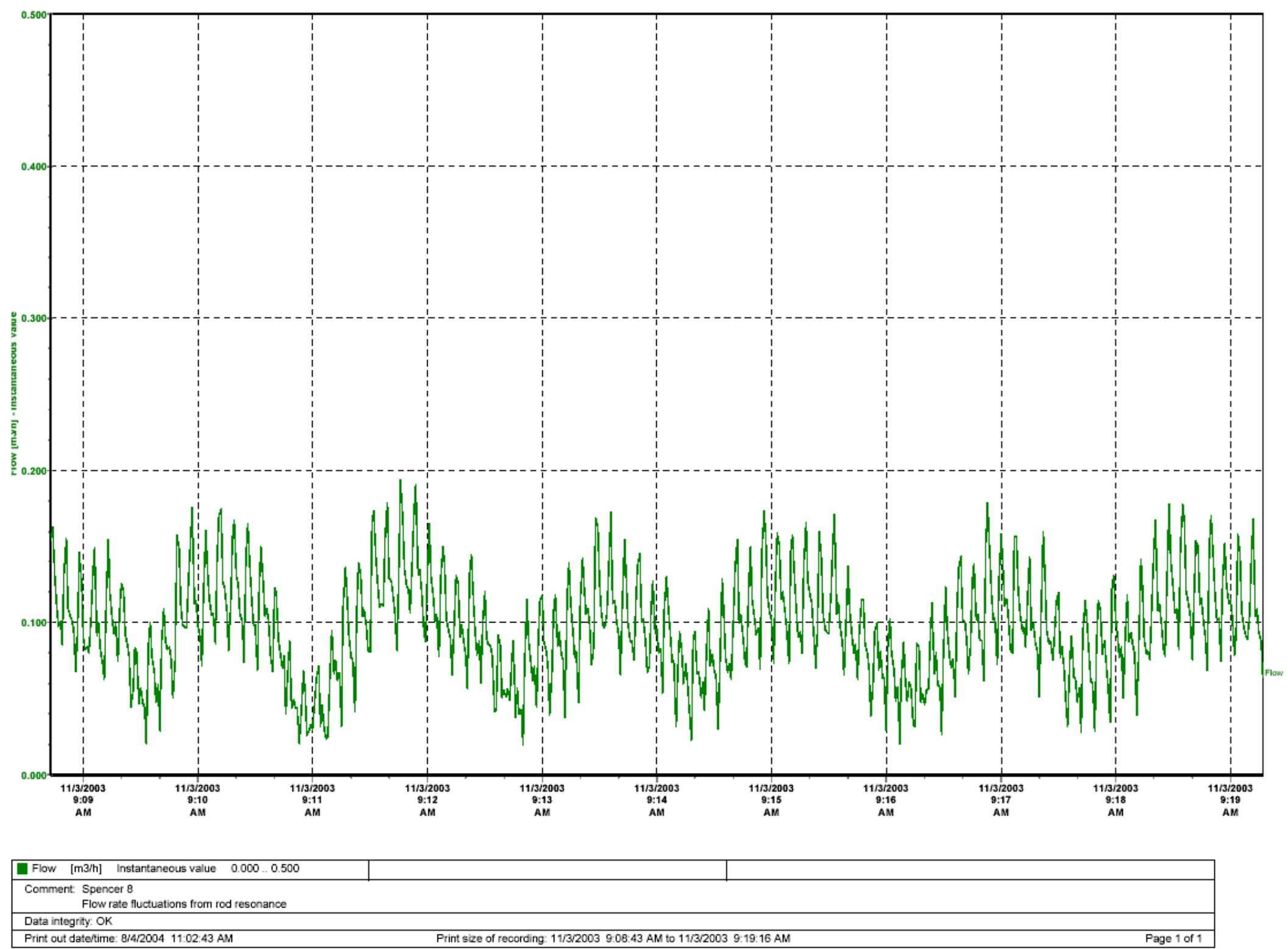

Figure 10

The resonance effect of the rod string acting like a spring is detected by the flow meter on the Spencer \#8 well. Each stroke of the pumping unit can also be seen. The well was producing from a depth of $831.19 \mathrm{~m}(2727 \mathrm{ft})$ utilizing 1.59 $\mathrm{cm}(5 / 8)$ diameter rods. 


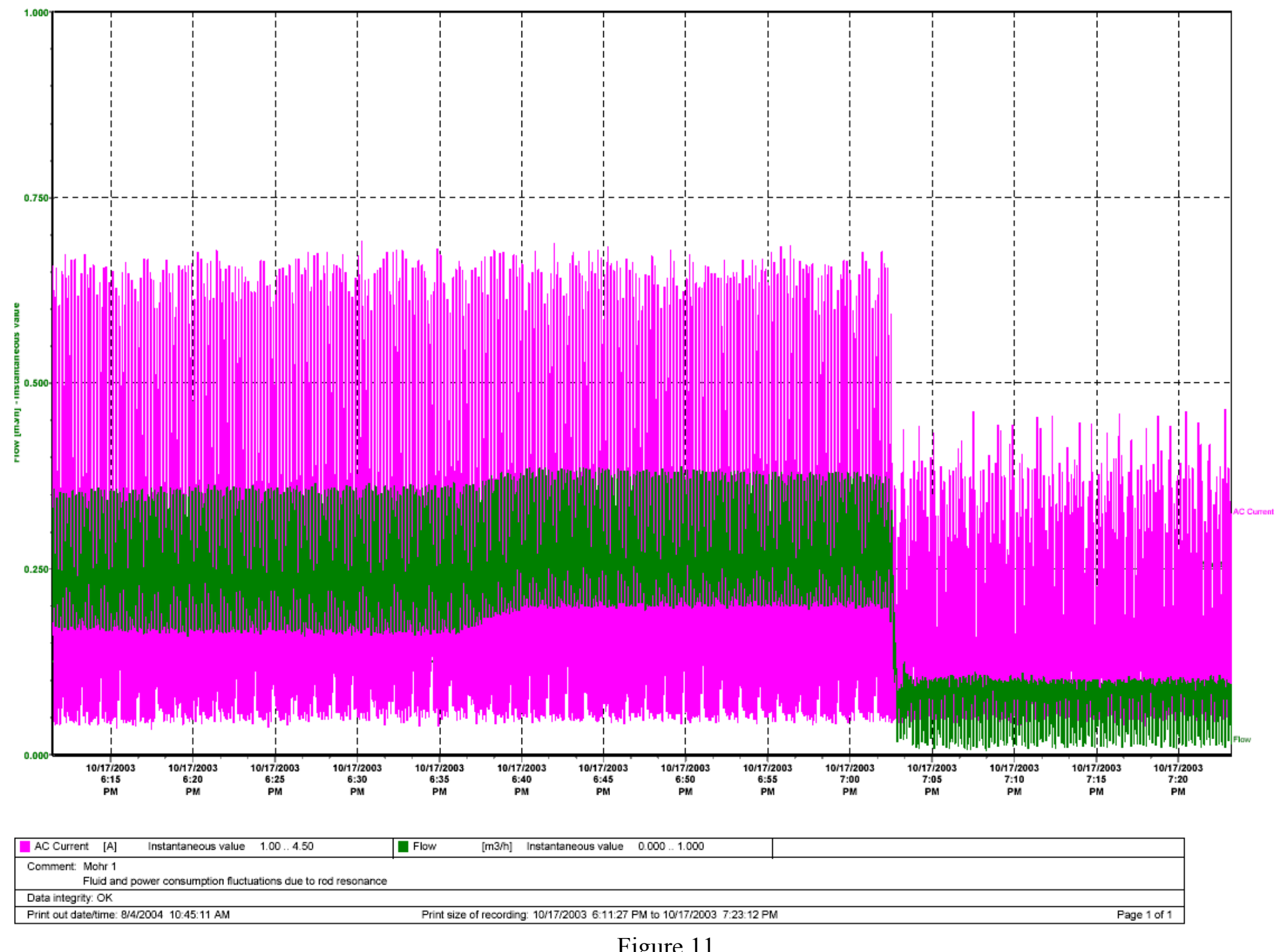

Figure 11

The resonance effect of the rod string acing like a spring is detected by the flow and amperage meters on the Mohr \#1 well. It was producing from $619.96 \mathrm{~m}$ (2034 ft) utilizing $1.59 \mathrm{~cm}(5 / 8 ”)$ diameter rods. 


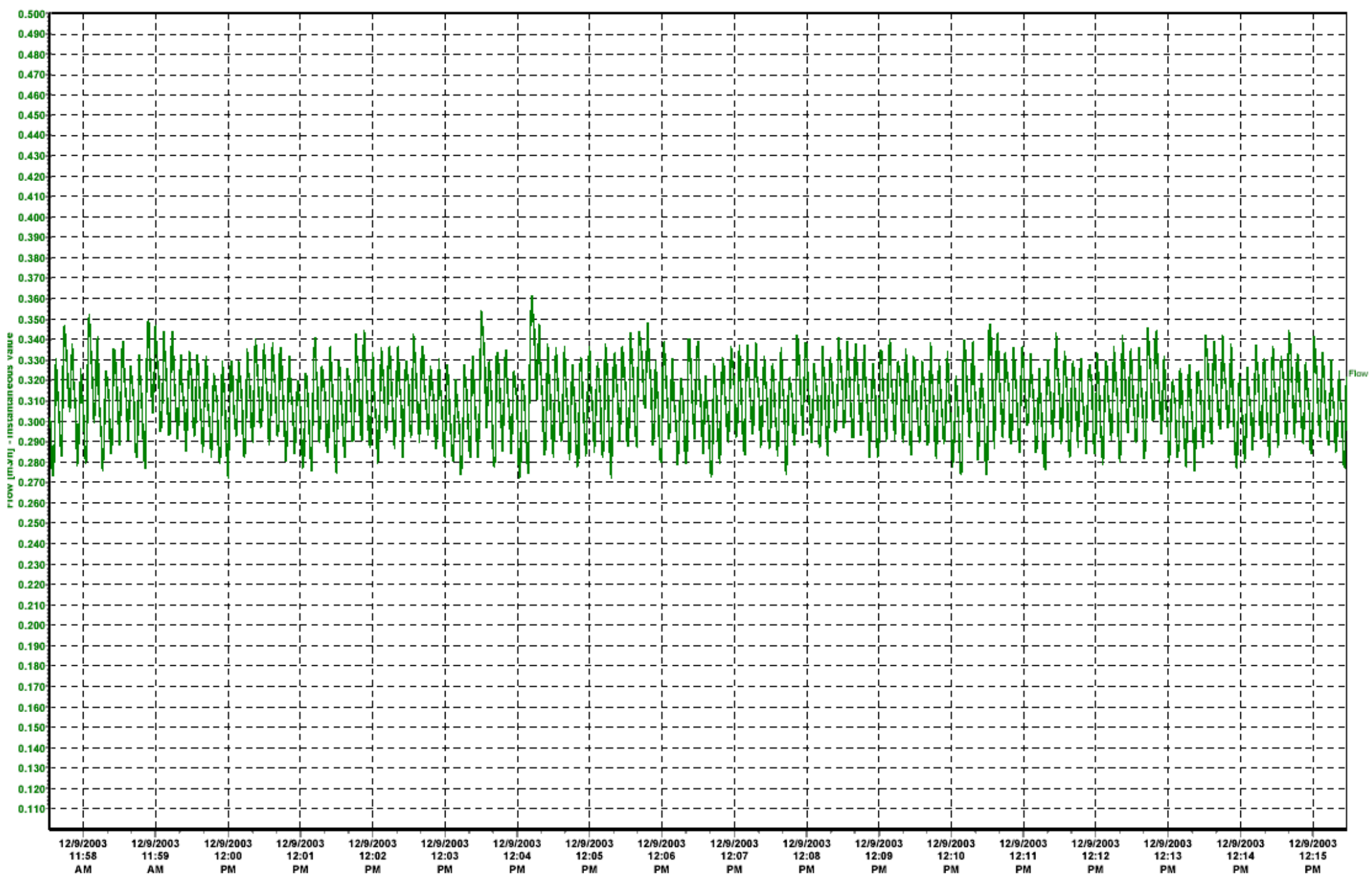

\begin{tabular}{|l|l|l|}
\hline Flow $[\mathrm{m} 3 / \mathrm{h}] \quad$ Instantaneous value $\quad 0.100 \ldots 0.500$ & \\
\hline $\begin{array}{l}\text { Comment: AGU \#1 } \\
\text { Flow rate fluctuations from rod resonance }\end{array}$ \\
\hline Data integrity: OK $\quad$ Print size of recording: 12/9/2003 11:57:32 AM to 12/9/2003 12:15:27 PM \\
\hline Print out datertime: 8/4/2004 1:30:19 PM
\end{tabular}

Figure 12

The resonance effect of the rod string acting like a spring is detected by the flow meter on the AGU \#1 well. It was producing from $423.06 \mathrm{~m}(1388 \mathrm{ft})$ utilizing $1.59 \mathrm{~cm}(5 / 8 ”)$ diameter rods. 